\title{
Habitat Suitability Mapping of Rastrelliger Brachysoma Using MODIS Image in WPP 711
}

\author{
Prama Ardha Aryaguna \\ Department of Survey and Mapping, Faculty of Engineering, Universitas Esa Unggul, Jakarta Barat
}

Received: 2019-02-12 Accepted: 2019-07-17

\section{Keywords:}

Habitat Suitability,

Species Distribution Modeling

MODIS

Rastrelliger brachysoma

Corespondent Email:

prama.ardha@esaunggul.ac.id

\begin{abstract}
Important factors that needs to be understood in the management of fishery resources is fish habitat. Fish habitat is an ideal water conditions of a fish species to spawn, breed, feed and grow into adults. Distribution of fish habitat can be approach using variety method, such Habitat Suitability/Species Distribution Modeling. Remote sensing analysis is effective method in providing daily oceanography information. Modis is Remote sensing imagery can be used for modeling Rastrelliger brachysoma fish habitat. Date acquired MODIS image at 28 March 2015, depend on existing field data. The results indicate that, the highest probability of Rastrelliger brachysoma fish habitat location in WPP 711 are in the middle waters of the WPP border between the deep sea of Indonesia and the Pacific Ocean. The lowest probability value for habitat of Rastrelliger brachysoma fish is in the southern shallow waters of Bangka Belitung island which is around 0.1-0.25.
\end{abstract}

2019 by the authors This article is an open access article distributed under the terms and conditions of the Creative Commons Attribution(CC BY NC) licensehttps://creativecommons.org/licenses/by-nc/4.0

\section{Introduction}

Indonesia is an archipelago country, most of which is the ocean. The marine fisheries sector in Indonesia is one of the main activities that contribute to the national economy and also as part of national economic development, which has the aim of improving the living standards and welfare of fishermen (Apriliani et al 2018; Nurdin et al 2017). Indonesian Sea has various types of fish because Indonesia is located in the tropical region. Each fish species has its own habitat depending on the physical or chemical structure they have. Complex interactions of the physical, chemical, and biological processes of the oceans at sea level affect biological processes, and ultimately determining the distribution of pelagic fish and natural variations in fish stocks (Solanki et al. 2005).

Habitat is about the environment for productivity, development, maintenance and distribution of reproduction. Changes to major environmental variables may impact the abundance, distribution, and availability of fish populations (Pitchaikani \& Lipton 2012). The biotic diversity and abundance can be influenced by the structural complexity of the habitat, however, the influence of the structural complexity of the habitat on marine ecosystems is rarely discussed. The understanding of the relationship between fish distribution and environmental factors is very important in order to explore fisheries resources (Nurdin et al. 2017). Fish habitat is closely related to certain values of oceanographic properties, such as sea surface temperature and chlorophyll-a (Semedi \& Hadiyanto 2013).
In Indonesia in particular, local fishermen still use "Pranata Mangsa" for sailing guides to detect the spatial distribution of fish locations and seasons (Partosuwiryo. 2009). This knowledge was passed from generation to generation and becomes a tradition and culture that is inherent in every local fisherman (Budiono 2004). The problem that arises at this time is the global climate change, which has an impact on oceanographic conditions that affect the migration patterns and presence of fish both vertically and geographically (Rijnsdorp et al. 2009). Climate change makes "Pranata Mangsa" is not suitable enough to be used as a sailing guide for fishermen when fishing.

Technology development such as remote sensing and Geographic Information System (GIS) provide faster and more detailed information. Remote sensing and GIS are powerful tools for detecting fishing locations, which are important in preserving fish for humans (Shaari and Mustapha, 2018). Various methods were developed to obtain information updates and increased accuracy, especially for mapping the suitability of fish habitat. IDRISI is one of the GIS software that develops habitat suitability models and species distribution modeling. Rastrelliger brachysoma was chosen for this study because the capture of Rastrelliger brachysoma species is carried out every day, and it is feared there will be a decrease in quantity. This decrease is caused by the fishermen that fish continuously in the same location, since they are only rely on local knowledge. This does not give enough time for the fish to respawn, while in 
other locations the Rastrelliger brachysoma is still not fished effectively. Therefore, assessment is needed to test how effective this method to model marine species such as Rastrelliger brachysoma, so that it can help fishermen more efficiently when fishing in the sea.

\section{The Methods}

The research location is one of the Fisheries Management Areas, or abbreviated as WPP. WPP is determined by the Minister of Marine Affairs and Fisheries. This study took part in one of the WPPs in Indonesia, namely WPP 711 (Figure 1). WPP 711 includes the Karimata Strait, Natuna Sea and the South China Sea. WPP 711 also includes 10 provincial fishing ports, namely Riau, Riau Islands, Jambi, South Sumatra, Bangka Island, Belitung, DKI Jakarta, West Java, Central Java and West Kalimantan. WPP 711 is geographically located on the border between deep waters and shallow waters, which are highly potential for fisheries. Based on the CTF data in 2014, the production of Rastrelliger brachysoma decreased 2.5\% per year from 2010 - 2013 (Komalasari 2016). The location of the WPP 711 was chosen because of the availability of logbook fishing data from fishermen.

\section{Sea Surface Temperature}

MODIS satellite imagery is an ocean color satellite that has a higher spatial resolution than NOAA or Aquarius, which can be used to analyze Chlorophyll-a Concentrations, Sea Surface Salinity (SSS) and Sea Surface Temperature (SST). MODIS image processing into SST values is performed using band 31, 32 and sensor zenith based on relationship between temperature and blackbody (Franz, 2006). The first step is to convert the brightness values of bands 31 and
32 using Equation 1. Brightness values are converted to Brightness Temperature using the Planck function.

$\mathrm{Tb}=\mathrm{c} 2 /\left(\mathrm{Vi}^{*} \ln \left(\mathrm{c} 1 /\left(\mathrm{Vi} 5^{*} \mathrm{~b} 1\right)+1\right)\right)$.......(Equation 1$)$ (Brown \& Minnett, 1999)

$\mathrm{Tb}=$ Brightness Temperature $\left({ }^{\circ} \mathrm{K}\right)$,

$\mathrm{c} 1, \mathrm{c} 2=$ Constanta radiation, $\mathrm{c} 1$ value is $1.1910659 \mathrm{x}$

108 [W m-2 sr-1 ( $\mu \mathrm{m}-1)-4]$, and

c2 value is $1.438833 \times 104$ [K $\mu \mathrm{m}$ ]

$\mathrm{Vi}=$ (central wavelength),

b1 $=$ spectral band 20,31 and 32

Vi value is the central wavelength, which can be obtained from EOS data product handbook volume 2, 2000 (Parkinson \& Greenstone, 2000) and EOS data product handbook volume 1, 2004 (King et al. 2004) (Table 1ᄀ). MODIS sensor were installed in two satellites, MODIS and TERRA. This research using AQUA MODIS since there is no difference between them in processing Oceanography information, and also the differences of the absolute DPVOs of Chl-a and nFLH are relative small between Aqua and Terrra (Feng \& Hu, 2016). However, Franz et al. (2008) shows that MODIS-Terra instrument characterization errors impact the ocean color products, and show that the residual errors in the current operational calibration increased the cross-scan artifacts, mirrorside differences, and detectors-to-detector strips in the

Table 1. Center wavelength of AQUA MODIS Band.

\begin{tabular}{ccc}
\hline Image MODIS & Band 31 & Band 32 \\
\hline AQUA & 11.0263 & 12.0424 \\
TERRA & 11.0073 & 12.0020 \\
\hline
\end{tabular}

EOS Handbook 2 2000; EOS Handbook 1, 2004

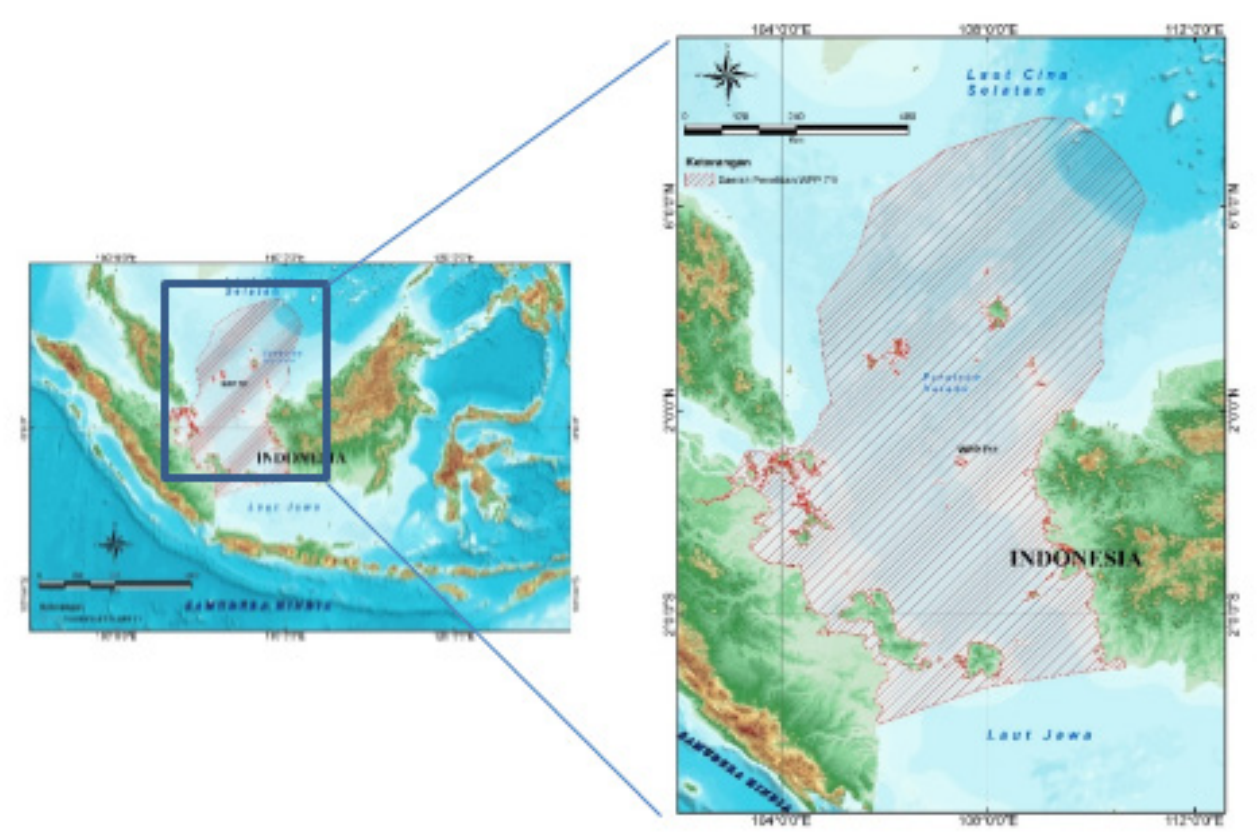

Figure 1. The location of the research area. 
retrieved water leaving radiances.

The zenith sensor must be converted to the zenith angle radiance value using Equation 2.

$\mathrm{Rz}=\mathrm{R} \_s c a l e z * \mathrm{~b} 1^{*}(\pi / 180)$ (Equation 2)

(Vermote et al. 2011)

Note:

R_scalez : Scale factor value (from image metadata) B1 : Zenith Band

Pi : 3,14

The preparation of input data requires a layer stacking process that includes bands 20,31, 32 and zenith angles, thus becoming single dataset. The layer stacking process aims to simplify the processing of SST parameters into SST (Figure 2).

Processing of Sea Surface Temperature can be done using two datasets, namely MODIS day recording and MODIS night recording dataset. This study uses MODIS

Table 2. Coefficient of SST formula (Davies, 2004)

\begin{tabular}{lrrrr}
\hline Satellite & $\mathrm{k} 1$ & $\mathrm{k} 2$ & $\mathrm{k} 3$ & $\mathrm{k} 4$ \\
\hline Terra & -0.065 & 1.034 & 0.723 & 0.972 \\
Aqua & 0.987 & 1.031 & 0.349 & 1.766 \\
\hline
\end{tabular}

dataset recorded during the day because it adjusts to the location of fish catch samples that day.

Table 2 above is the input for obtaining parameters for calculating SST. The equation for calculating SST can be seen in equation 3 .

SST day $=\mathrm{k} 1+\mathrm{k} 2 \times$ B31celcius $+\mathrm{k} 3 \times$ (B31kelvinB32kelvin) $\mathrm{x}$ BSSTcelcius $+\mathrm{k} 4 \mathrm{x}$ (B31kelvin-B32kelvin) $\mathrm{x}(1 / \cos$ (theta) -1$)$ (Equation 3) (Brown \& Minnett, 1999)

Note:

$\mathrm{k} 1-\mathrm{k} 2$

$=$ Coefficient of SST (Table 2)

$\mathrm{B} 31-\mathrm{B} 32$

$=$ Band 31 and 32

Theta = Zenith Angle

BSST = Brightness Temperature Band 20
Sea Surface Salinity (SSS) Processing

There are two algorithms for converting MODIS image pixel values to SSS values, namely through formulas reported in the corresponding ATBD (Theoretical Based Document Algorithm) No. 277 and through the CDOM (Colored Dissolved Organic Matter) approach. The CDOM approach is an algorithm proposed by $\mathrm{Hu}$ et al. (2004), which states that CDOM is the only element component that is related and has an inverse relationship with SSS. The SSS is not easily observed using remote sensing, especially from MODIS images in bands with $200 \mathrm{~m}$ or $500 \mathrm{~m}$ spatial resolution.

Algorithm MLR (Multiple Linear Regressions) was developed by (Wong et al., 2007) as shown in Table 4 . It has high correlation between salinity model from algorithm and measured salinity (Figure 3 ). The algorithm can be seen in Equation 4. Algorithm from (Wong et al., 2007) needs input from seven spectral bands. Every band has a constant obtained from previous research and regression between measured salinity and pixel value of each spectral band.

SSS $(\mathrm{psu})=14.256-240.163{ }^{*}$ Band $1-72.533{ }^{*}$ Band 2 $+124.700 *$ Band $3+191.266{ }^{*}$ Band $4+36.044^{*}$ Band 5- $11.117 *$ Band $6-39.789 *$ Band 7......(Equation 4) (Wong et al., 2007)

\section{Chlorophyll-a extraction}

The method for obtaining Chlorophyll-a through MODIS images is with the OC $3 \mathrm{M}$ formula adapted from the OC4 and OC2 algorithms. OC4 and OC2 methods were developed for Sea WiFS images and adjusted for MODIS with modifications. The results of the algorithm provide a range of values between 0.00008 to $90 \mathrm{mg} / \mathrm{m} 3$ (Chen \& Quan, 2013). The OC3M algorithm was used by NASA Ocean Color Group to process MODIS imagery into a standard product of MODIS Chlorophyll-a concentration (Chen \& Quan, 2013; Komick et al., 2009). The calculation of chlorophyll-a concentration using the OC $3 \mathrm{M}$ algorithm can be seen in Equation 5 and Equation 6.
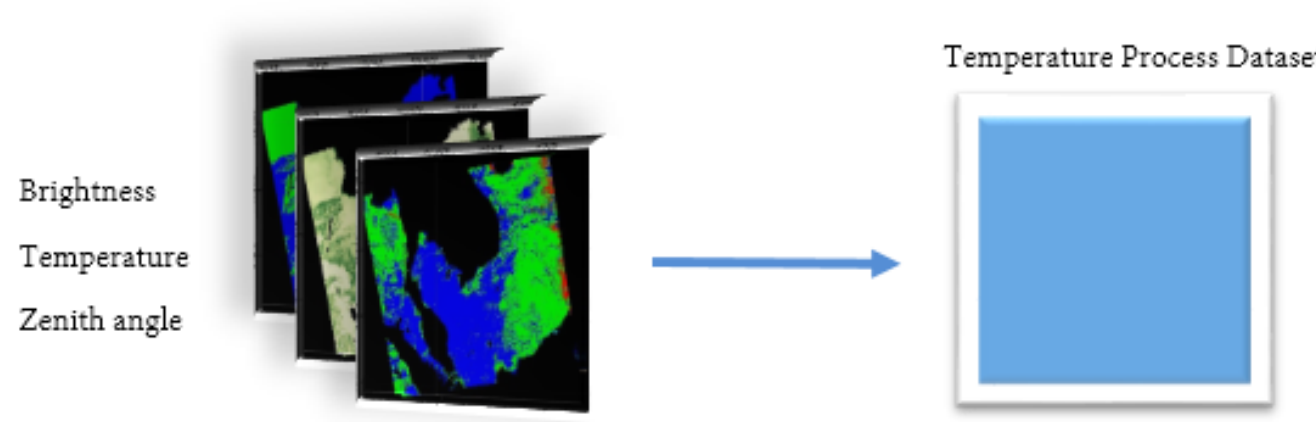

Figure 2. Stacked images of SST Parameter. 
Table 3. Source of data used in this work

\begin{tabular}{llll}
\hline Data name & Data Information & Source & Acquired from \\
\hline MODIS Image & - SST & NASA government & http://modis.gsfc.nasa.gov/ \\
& - Chlorophyll-a & & \\
& - Salinity & & \\
$\begin{array}{l}\text { Feedback / Fisherman or } \\
\text { researcher logbook }\end{array}$ & Fish catch location & $\begin{array}{l}\text { Minister of Marine and } \\
\text { Fisheries or Institute For } \\
\text { Marine Research And } \\
\text { ebservation }\end{array}$ & \\
WPP & WPP Border & $\begin{array}{l}\text { Minister of Marine and } \\
\text { Fisheries }\end{array}$ & $\begin{array}{l}\text { Minister of Marine and Fisher- } \\
\text { ies Regulation No. 1 Year 2009 }\end{array}$ \\
\hline
\end{tabular}

Table 4. Multiple Linear Regressions using $250 \mathrm{~m}$ and $500 \mathrm{~m}$ spatial resolution spectral bands.

\begin{tabular}{lll}
\hline Index & $500 \mathrm{~m}$ & $250 \mathrm{~m}$ \\
\hline SSS & $0.81($ Eq 7$)$ & 0.13 \\
& {$[\mathrm{P}<0.0001]$} & {$[\mathrm{P}=0.004228]$} \\
SS & $0.82($ Eq 5$)$ & $0.65(\mathrm{Eq} 6)$ \\
& {$[\mathrm{P}<0.0001]$} & {$[\mathrm{P}<0.0001]$} \\
\hline
\end{tabular}

Source: (Wong et al., 2007)

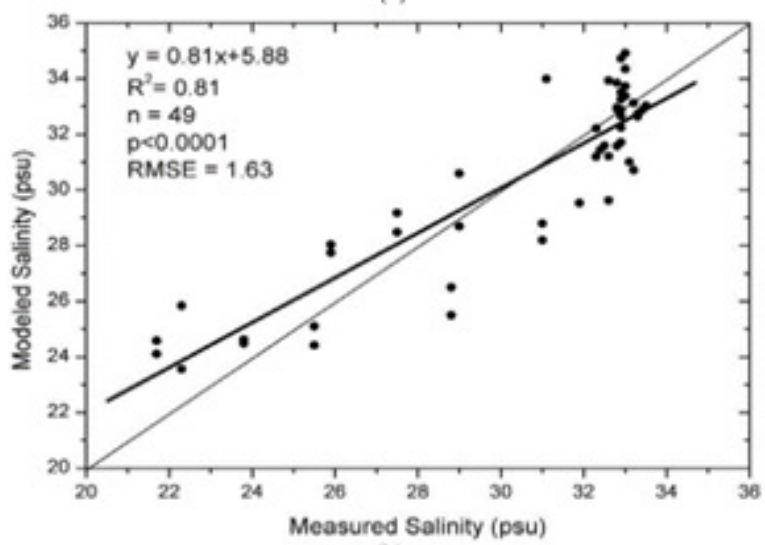

(b)

Figure 3. scatter plot between modeled salinity and measured salinity (Wong et al., 2007).
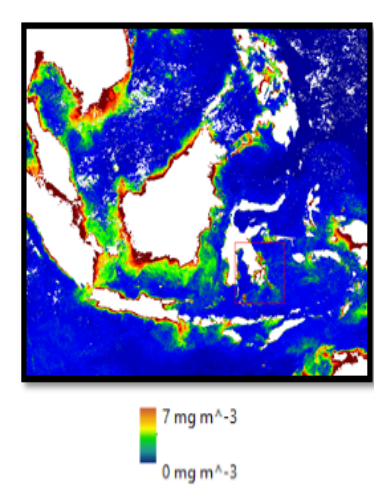

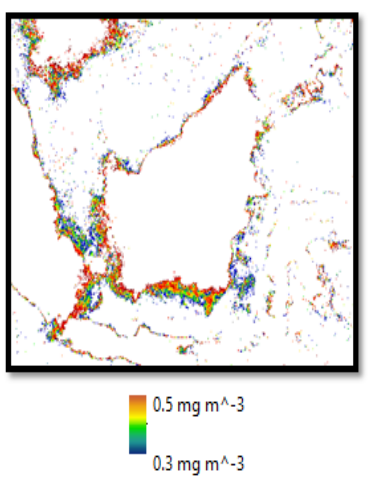

Figure 4. Sample Chlorophyll -a distribution (a)

Chlorophyll -a distribution; (b) Chlorophyll-a Mask $0.2-0.5 \mathrm{mg} / \mathrm{m} 3$.
$[$ chla $]=10^{\wedge}((0.2830-2.753 R+1.457 R 2+0.659 R 3-$ 1.403R4) .........(Equation 5)

(Komick et al., 2009)

$\mathrm{R}=\log 10\{\max R[\operatorname{Rrs}(443 \mathrm{~nm}), \operatorname{Rrs}(488 \mathrm{~nm})]\} /(\operatorname{Rrs}$ $(551 \mathrm{~nm}))$.................(Equation 6)

(Komick et al, 2009)

Based on Insanu et al. (2013), the optimum concentration of Chlorophyll-a for potential fish locations is $0.2-1.0 \mathrm{mg} / \mathrm{m} 3$. This range can be used to narrow potential fish locations so that the results are more accurate.

\section{Habitat Suitability / Species Distribution Modeling}

For habitat suitability mapping, the variables used are related to oceanographic parameter of habitat types, at time series. All variable types must be continuous variables, because habitat mapping has dynamic properties and is always changing unless multicriteria evaluation is used. This method uses training samples from fishing logbooks by fishermen. The modeling algorithm uses the Mahalanobis Typicality approach. Habitat suitability modeling results were then compared with the FAO habitat suitability maps (Carroci, 2009).

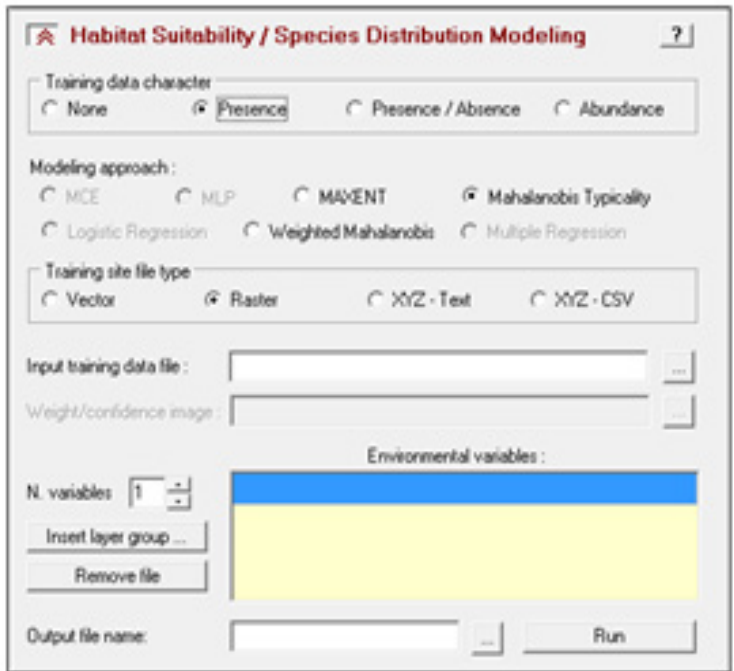

Figure 5. Habitat Suitability Modeling Tools using IDRISI. 
Mahalanobis Typicality Approach

This modeling approach assumes that species distribution is normal and is influenced by environmental gradients. The model was used to determine the distribution of the existence of species. The results of habitat suitability modeling are probability values, which are the expression of how typical each pixel is compared to the training sample. The range of probability values is between $0.0-1.0$. Values closer to 1.0 indicate that the location is identical to the average environmental conditions proven in the training sample. Low probability values at certain locations may still be suitable for the habitat of certain species, especially if the species habitat is very specific.

Mahalanobis distance is a statistical knowledge that explains the size of distance (Foody et al., 1992), and is a multivariate equivalent to the $\mathrm{z}$-score (Li \& Fox, 2011) (Equation 7).

$\mathrm{D}=\sqrt{ }\left(\left(\mathrm{x}-\mu \_\mathrm{i}\right)^{\wedge} \mathrm{T} \mathrm{V} \_\mathrm{i} \wedge(-1)\right)\left(\mathrm{x}-\mu \_\mathrm{i}\right)$

(Li \& Fox, 2011)

The use of Mahalanobis distance methods give advantages to determine the similarity of an unknown sample to a known group of samples (Li \& Fox, 2011). Figure 6 shows that the typicality probability can be defined as the probability of any case, problems or location which having a Mahalanobis distance greater or equal to case, problem or location at the research location (Figure 6). Locations which having identical attributes to the multivariate centroid have a typicality probability of 1.0, and location which having less typical locations have typicality probability of 0.0 at the limits of the distribution (Li \& Eastman, 2010). The concept of typicality probability show which values of

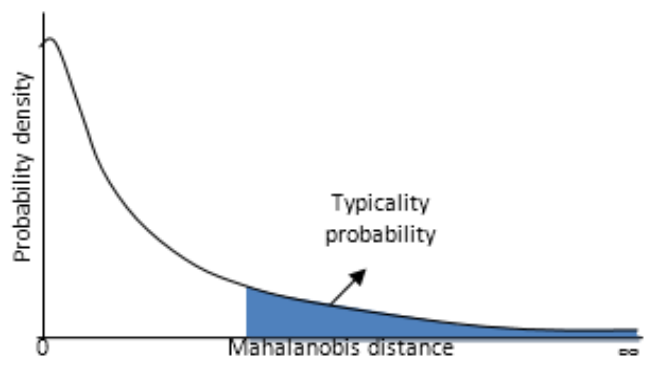

Figure 6. Illustration of the Mahalanobis typicalities (Li \& Fox, 2011).

input variables at a location are typical with specific class training sampel (Foody et al., 1992; Eastman, et al., 2005).

The characteristics of class membership were obtained from the maximum likelihood algorithm. The typicality probability define a problem into a particular class because of the absolute size of a class membership (Foody, 2002). A very low typicality probability can be used to indicate that the problem is actually a member of an untrained class (Foody, 2002). Recently, Mahalanobis typicality has been applied to species distribution modeling (Hernandez et al., 2008).

\section{Result and Discussion}

Based on the oceanographic modeling using MODIS imagery, three oceanographic parameters will be used to model habitat suitability for Rastrelliger brachysoma. These parameters are chlorophyll-a, SST and SSS. Based on the modeling results, the value of chlorophyll-a in WPP 711 ranges from $0.20-0.88 \mathrm{mg} /$ $\mathrm{m} 3$. Chlorophyll-a which has a value of more than 0.70

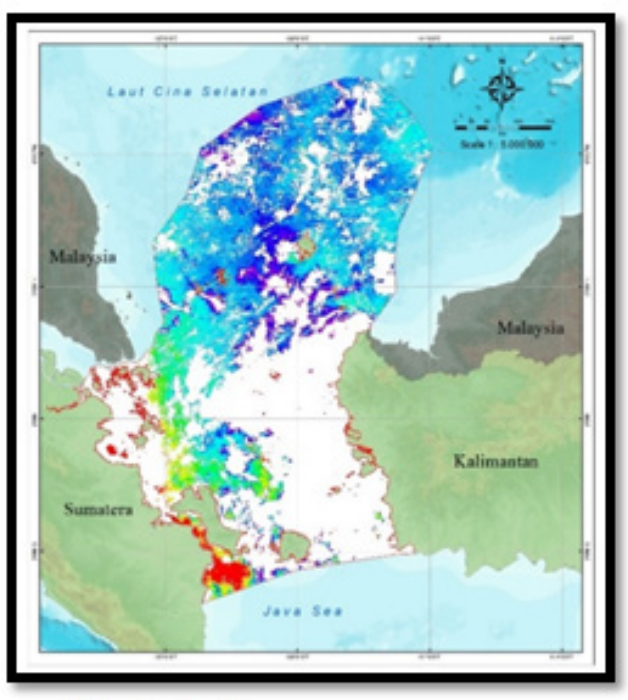

Chl-a $(\mathrm{mg} / \mathrm{m}-3)$

High : 1.49544

Low : 0.267986

(a)

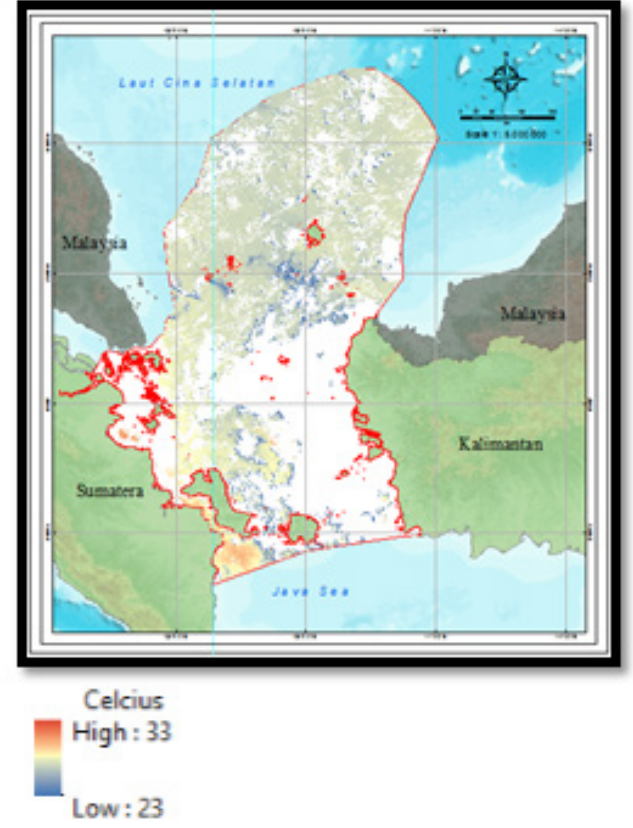

(b)

Figure 7. (a) Chlorophyll-a Modeling result, (b) Sea Surface Temperature Modeling result. 


\section{Temperature Value $\left({ }^{\circ} \mathrm{C}\right)$}
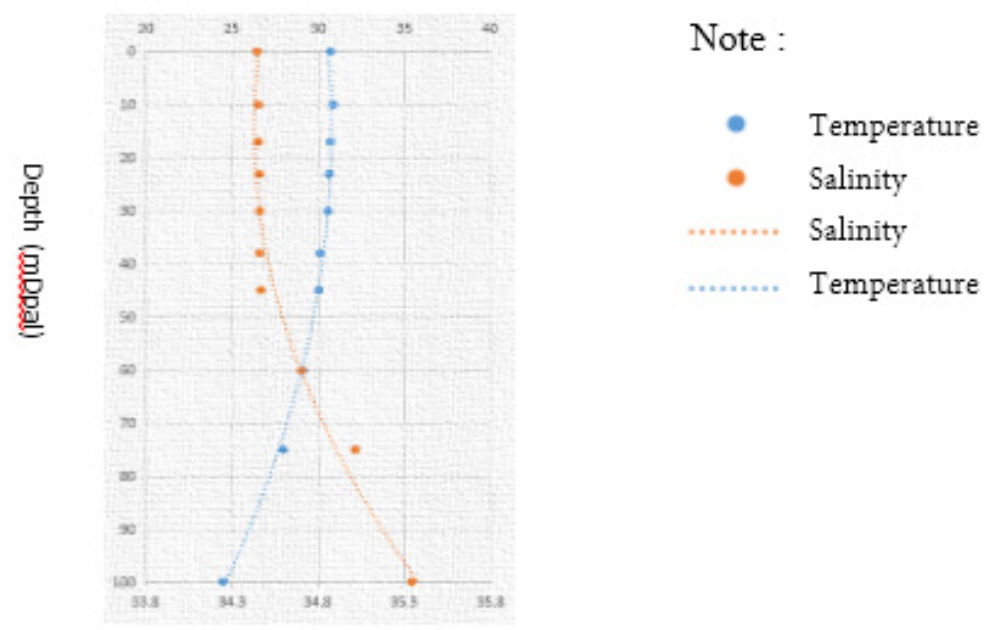

Salinity Value (PSU)

Figure 8. The SSS and SST graph for different depths (Aryaguna et al. 2017.

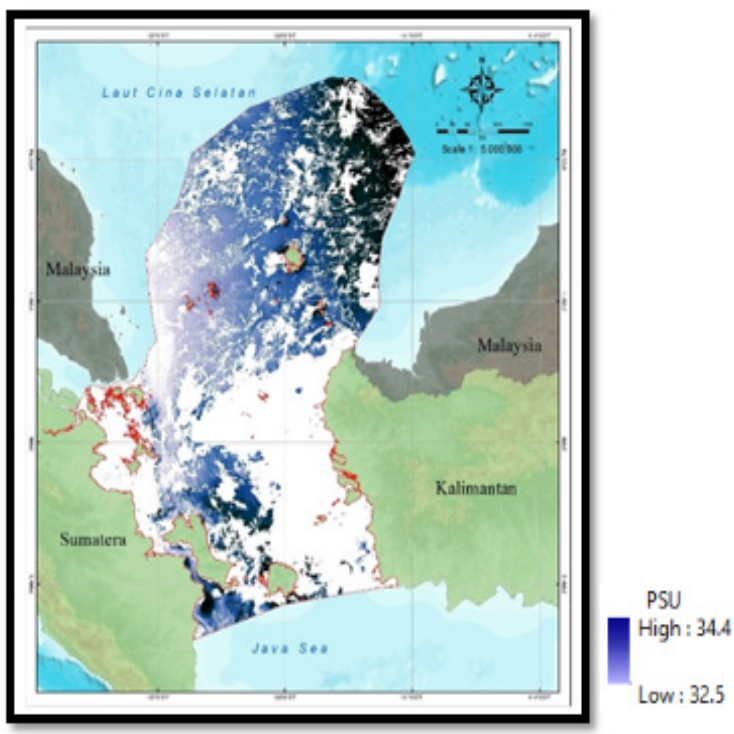

Figure 9. Sea Surface Salinity Modeling Result.

$\mathrm{mg} / \mathrm{m} 3$ is located on the coast and in the water between Sumatera Island and Bangka Belitung Island. The effect of high sedimentation in coastal areas can affect the value of chlorophyll-a from modeling results. For offshore water, especially those heading to the water of the South China Sea, the value of chlorophyll-a is lower, which is less than $0.3 \mathrm{mg} / \mathrm{m} 3$.

The modeling of SST using MODIS imagery shows that the range of SST in WPP 711 is between $23-33^{\circ} \mathrm{C}$. Spatially, the SST gets colder towards open water, this is influenced by the depth of the sea. The temperature in the water near the land is between $30-33^{\circ} \mathrm{C}$, while in the deep water leading to the South China Sea is around $25-23^{\circ} \mathrm{C}$. This value indicates that the upwelling process occurred, because warmer water is replaced with cooler water from deep water. The upwelling process occurs

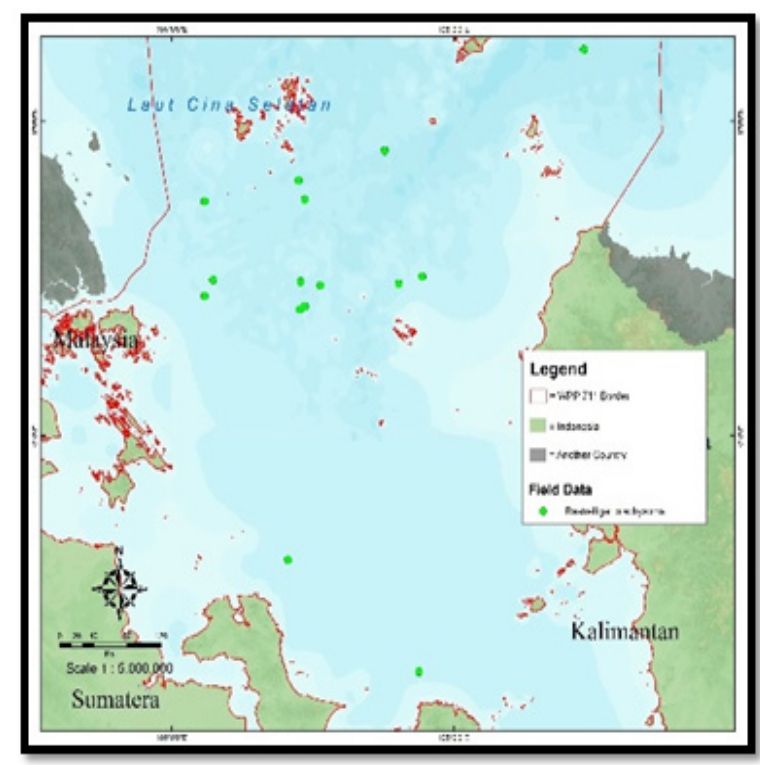

Figure 10. Sample distribution of Rastrelliger brachysoma catch.

more often in deeper waters than shallow waters (Figure 8). In addition, errors can also occur due to cloud shadows, which make the predicted SST lower than the actual conditions in the field.

The value of SSS is strongly influenced by sun conditions and the effects of rain, especially because the study area is in the tropics. High salinity can be caused by low evaporation due to lack of sunlight, besides that high salinity can also be affected by the depth of the sea in the area (Richaud et al, 2016). Based on Figure 9 , the deeper the sea, the higher the salinity because the sun cannot penetrate so that no light enters and causes deeper waters to have higher salinity. The value of water salinity in the study area has a range of values between 32 - 34 PSU. 


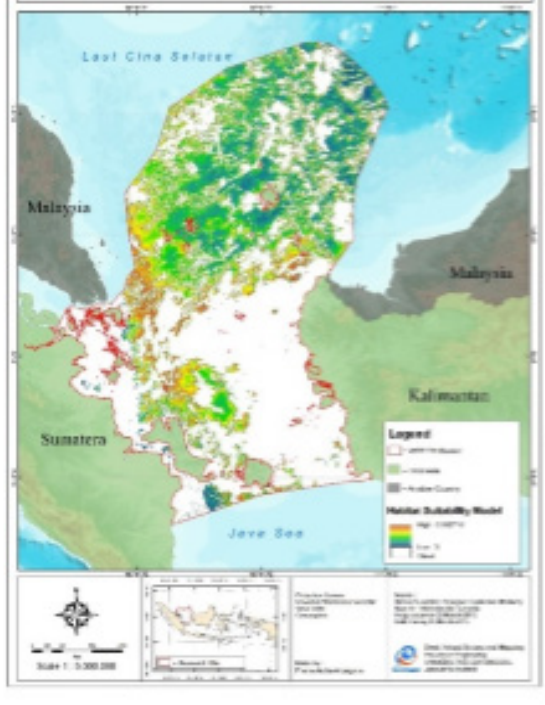

(a)

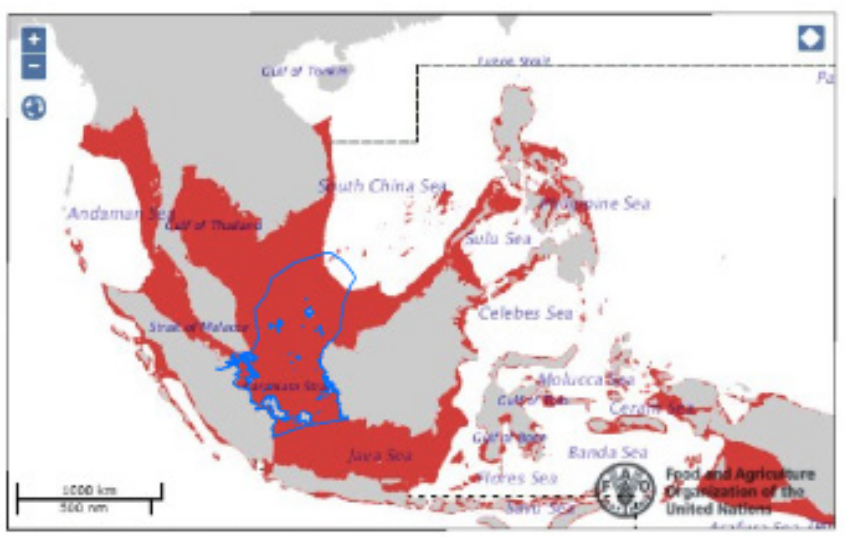

(b)

Figure 11. Habitat Suitability Model of Rastrelliger brachysoma (a) Model Result, (b) FAO result (Carroci, 2009).

Habitat suitability modeling did not only require oceanographic parameters, but also require samples of fishing locations. The fishing locations data was obtained through fisherman logbooks collected from the Ministry of Marine Affairs and Fisheries (KKP). The distribution of Rastrelliger brachysoma fishing location data can be seen in Figure 10.

The probability of habitat suitability of Rastrelliger brachysoma is based on the location of fish discovery and its constituent parameter values. The modeling results show that the highest habitat suitability of Rastrelliger brachysoma is in the south of WPP 711, which is in Indonesian waters. In the South China Sea region or deeper waters, the suitability of Rastrelliger brachysoma habitat is decreasing. The modeling results have the same pattern as the data produced by FAO (Figure 11), where the South China Sea is not suitable as a habitat for Rastrelliger brachysoma.

\section{Conclusion}

The spatial distribution of habitat suitability of Rastrelliger brachysoma can be modeled if we have fish catch location data and several oceanographic parameters such as SST, chlorophyll-a concentration, and SSS. Oceanographic parameters can be obtained from MODIS image analysis, both using formulas in the ATBD or by performing empirical modeling between MODIS pixel values and oceanographic information in the field. In general, towards the South China Sea, the water is increasingly less suitable as a habitat for Rastrelliger brachysoma. The fish habitat modeling results have the same pattern as the Fishbase habitat distribution map produced by FAO. However, the information produced in this research is more detailed because the results are not only binary, but produced a probability value.

\section{References}

Apriliani, I. M., Nurrahman, Y. A., \& Dewanti, L. P. (2018). Determination of potential fishing ground for hairtail ( Trichiurus sp .) fishing based on chlorophyll- a distribution and sea surface temperature in Pangandaran waters, West Java ,. AACL Bioflux, 11(4), 1047-1054.

Aryaguna, P., Kamal, M., \& Hartono. (2017). Analisis Penginderaan Jauh untuk Data Oseanografi : Perbandingan Salinitas dan Suhu pada Permukaan dan Kolom Air di Wilayah Pengelolaan Perikanan 711 ( WPP 711 ). In 5th Geoinformation Science Symposium (Vol. 711, pp. 149-160). Yogyakarta. Retrieved from http:// puspics.ugm.ac.id/snsg2017/

Budiono, A. (2004). No TitleStudi Sebaran Fishing Ground Tuna Mata Besar (Thunnus obessus) Berdasar Kondisi Oseanografi di Perairan Selatan Jawa Pada Musim Timur. Universitas Diponegoro.

Brown. O., Minnett, P. (1999). MODIS Infrared Sea Surface Temperature Algorithm : Algorithm Theoretical Basis Document Version 2.0. University of Miami.

Carroci, Fabio. (2009). Aquatic Species Distributio Map Viewer : Rastrelliger brachysoma. Retrieved from http://www.fao.org/figis/geoserver/factsheets/species. html? species $=$ RAB-m\&prj $=4326$.

Chen, J., \& Quan, W. (2013). An improved algorithm for retrieving chlorophyll-a from the Yellow River Estuary using MODIS imagery. Environmental Monitoring and Assessment, 185(3), 2243-2255. https://doi.org/10.1007/ s10661-012-2705-y

Eastman, J. R., Crema, S., Zhu, H., Toledano, J., \& Jiang, H. (2005). In-Process Classification Assessment of remotely sensed imagery. Geocarto International, 20(4), 33-43. https://doi.org/10.1080/10106040508542362

Feng, L., \& Hu, C. (2016). Comparison of Valid Ocean Observations Between MODIS Terra and Aqua Over the Global Oceans. IEEE TRANSACTIONS ON GEOSCIENCE AND REMOTE SENSING, 54(3), 15751585.

Foody, G. M. (2002). Hard and soft classifications by a neural network with a non-exhaustively defined set of classes. 
International Journal of Remote Sensing, 23(18), 3853 3864. https://doi.org/10.1080/01431160110109570

Foody, G. M., Campbell, N. A., Trodd, N. M., \& Wood, T. F. (1992). Derivation and applications of probabilistic measures of class membership from the maximumlikelihood classification. Photogrammetric Engineering and Remote Sensing, 58(9), 1335-1341.

Franz, B. (2006). Implementation of SST Processing within the OBPG. Retrieved December 7, 2018, from https:// oceancolor.gsfc.nasa.gov/docs/modis_sst/

Franz, B. A., Kwiatkowska, E. J., Meister, G., \& Mcclain, C. R. (2008). Moderate Resolution Imaging Spectroradiometer on Terra: limitations for ocean color applications, 2(June), 1-17. https://doi.org/10.1117/1.2957964

Hernandez, P. A., Franke, I., Herzog, S. K., Pacheco, V., Paniagua, L., Quintana, H. L., ... Young, B. E. (2008). Predicting species distributions in poorly-studied landscapes. Biodiversity and Conservation, 17(6), 13531366. https://doi.org/10.1007/s10531-007-9314-Z

Hu, C., Chen, Z., Clayton, T. D., Swarzenski, P., Brock, J. C., \& Muller-Karger, F. E. (2004). Assessment of estuarine water-quality indicators using MODIS mediumresolution bands: Initial results from Tampa Bay, FL. Remote Sensing of Environment, 93(3), 423-441. https:// doi.org/10.1016/j.rse.2004.08.007

Insanu, R., Handayani, H., \& Sukojo, B. (2013). Analisis Pemetaan Zona Penangkapan Ikan ( Fishing Ground ) Dengan Menggunakan Citra Satelit Terra Modis dan Parameter Oseanografi. Prosiding Seminar Nasiional Manajemenn Teknologi XVIII, (Murrachman 2006), B-27-1-B-27-13.

King, M., Closs, J., Spangler, S., Greenstone, R., Wharton, S., Myers, M. (2004). EOS Data Products Handbook Volume 1. NASA Goddard Space Flight Center; Greenbelt, MD, USA.

Komalasari, D. (2016). Dinamika Populasi Ikan Kembung Perempuan ( Rastrelliger brachysoma Bleeker, 1851) Di Perairan Selat Sunda. Institut Pertanian Bogor.

Komick, N. M., Costa, M. P. F., \& Gower, J. (2009). Bio-optical algorithm evaluation for MODIS for western Canada coastal waters: An exploratory approach using in situ reflectance. Remote Sensing of Environment, 113(4), 794-804. https://doi.org/10.1016/j.rse.2008.12.005

Li, Z., \& Eastman, J. R. (2010). Commitment and typicality measures for the Self-Organizing Map. International Journal of Remote Sensing, 31(16), 4265-4280. https:// doi.org/10.1080/01431160903246725

Li, Z., \& Fox, J. M. (2011). Integrating Mahalanobis typicalities with a neural network for rubber distribution mapping. Remote Sensing Letters, 2(2), 157-166. https://doi.org/1 $0.1080 / 01431161.2010 .505589$

Nurdin, S., Mustapha, M. A., Lihan, T., \& Zainuddin, M. (2017). Applicability of remote sensing oceanographic data in the detection of potential fishing grounds of Rastrelliger kanagurta in the archipelagic waters of Spermonde, Indonesia. Fisheries Research, 196(August 2016), 1-12. https://doi.org/10.1016/j.fishres.2017.07.029

Parkinson, C. Greenstone, R. (2000). EOS Data Products Handbook Volume 2. NASA Goddard Space Flight Center; Greenbelt, MD, USA

Partosuwiryo, S. (2009). Pranata Mangsa Sebagai Alterbatif Pedoman Untuk Penangkapan Ikan.

Pitchaikani, J. S., \& Lipton, a P. (2012). Impact of environment variables on pelagic fish landings: Special emphasis on Indian oil sardine off Tiruchendur coast, Gulf of Mannar. Journal of Oceanography and Marine Science, 3(3), 56-67. https://doi.org/10.5897/JOMS12.006

Richaud, B., Young-Oh, Kwon., Terrence, M., Paula, S., Steven, J. (2016). Surface and bottom temperature and salinity climatology along the continental shelf off the Canadian and U . S . East Coasts. Continental Shelf Research, Volume 124, 165-181. https://doi.org/ 10.1016/j.csr.2016.06.005

Rijnsdorp, A., Peck, M., Engelhard, G., Mo"llmann, C., \& Pinnegar, J. (2009). Resolving the effect of climate change on fish populations. ICES Journal Text, 15701583. Retrieved from http://icesjms.oxfordjournals.org/ content/early/2009/04/02/icesjms.fsp056.short

Semedi, B., \& Hadiyanto, a L. (2013). Forecasting the Fishing Ground of Small Pelagic Fishes in Makassar Strait Using Moderate Resolution Image Spectroradiometer Satellite Images. Journal of Applied Environmental and Biological Sciences, 3(2), 29-34. https://doi.org/10.13140/ RG.2.1.3920.2966

Shaari, N., \& Mustapha, M. (2018). Predicting Potential Rastrelliger kanagurta Fish Habitat using MODIS Satellite Data and GIS Modeling: A Case Study of Exclusive Economic Zone, Malaysia. Sains Malaysiana, 47(7), 1369-1378. https://doi.org/http://dx.doi.org/10.17576/ jsm-2018-4707-03 Predicting

Solanki, H. U., Dwivedi, R. M., Nayak, S. R., Naik, S. K., John, M. E., \& Somvanshi, V. S. (2005). Application of remotely sensed closely coupled biological and physical processes for marine fishery resources exploration. International Journal of Remote Sensing, 26(10), 2029-2034. https:// doi.org/10.1080/01431160310001595028

Vermote, E., Kotchenova, S. and Ray, J., (2011). MODIS Surface Reflectance User". Landsat Surface Reflectance Science Computing Facility, Greenbelt, MD, USA

Wong, M., Lee, K., Kim, Y., Nichol, J., Li, Z., \& Emerson, N. (2007). Modeling of suspended solids and sea surface salinity in Hong Kong using Aqua/MODIS satellite images. Korean Journal of Remote Sensing, 23(3), 161169. 